Author: Prof Gerrit Ferreira

RESPONSE TO PROF THILO MARAUHN'S OPENING ADDRESS ON 'LAND TENURE AND GOOD GOVERNANCE FROM THE PERSPECTIVE OF INTERNATIONAL LAW'

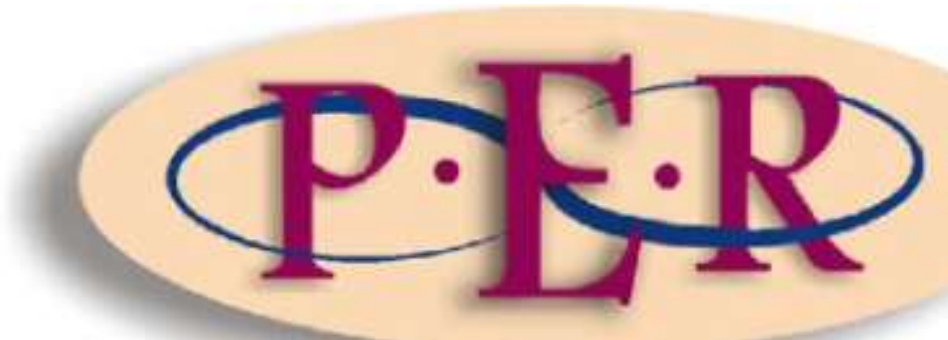

2011 VOLUME 14 No 3

http://dx.doi.org/10.4314/pelj.v14i3.2 


\section{RESPONSE TO PROF THILO MARAUHN'S OPENING ADDRESS ON 'LAND TENURE AND GOOD GOVERNANCE FROM THE PERSPECTIVE OF INTERNATIONAL LAW'}

G Ferreira $^{1}$

\section{$1 \quad$ Introduction}

I haven't had the privilege of reading prof Marauhn's contribution before my response this morning, but would nevertheless in my discussion focus on what I believe to be important pre-requisites for good governance on the international level. My contribution will therefore concentrate on what I would like to term good global governance; that is, good governance on the global or, if you so wish, the international level. Of course, the few remarks I wish to make will of necessity in certain respects also apply to the position in individual states.

\section{Discussion}

\subsection{Definition}

As a point of departure I would like to refer to the definition of good governance as formulated by the United Nations Economic and Social Commission for Asia and the Pacific. That body describes good governance as follows:

It is participatory, consensus orientated, accountable, transparent, responsive, effective and efficient, equitable and inclusive and follows the rule of law. It assures that corruption is minimized, the views of minorities are taken into account and that the voices of the most vulnerable in society are heard in decision-making. It is also responsive to the present and future needs of society.

It is implicit in this definition that good governance on the global or the international level may have profound implications for notions of established international law. It

Gerrit Ferreira. Professor of Public Law, Faculty of Law, North-West University (Potchefstroom

Campus).B luris, LLB (PUCHE). LLM (RAU), LLD (UNISA), LLD (PUCHE) (Gerrit.Ferreira@nwu.ac.za). 
will not, due to time constraints, be possible to discuss these notions extensively. A brief overview will have to suffice.

\subsection{International legal personality}

Good governance requires the inputs of a variety of role players including states, international and regional organisations, NGOs, multi-national corporations, minority groups and even individuals. Of these only states and international and regional organisations are recognised as subjects in public international law. In order to allow the others to play their full role in ensuring good governance, the question arises as to whether they should be granted some form of international legal personality. This would allow for proper control by the United Nations, for example, over the activities of these institutions on the international level.

\subsection{An international rule of law}

Good governance on the international level presupposes an international rule of law. Although many arguments can be advanced against the recognition and effective application of an international rule of law as opposed to a domestic or national rule of law, it is nevertheless a fact that the restructuring of international society through globalisation increasingly necessitates international relations to be governed by the rule of law. One of the most difficult issues in this regard relates to agreement being reached on the core values underpinning an international rule of law, and the creation of an international court with compulsory jurisdiction to enforce the values agreed upon. A particularly controversial area in which an international rule of law as part of good governance would have to operate is the promotion and protection of international human rights. As a result of and in view especially of the prevailing cultural and religious differences from nation to nation, the debate on universalism and cultural relativism in the context of the application of international human rights will have to be re-visited, as it is imperative that consensus be reached between states on at least a minimum number of human rights to be protected. 


\subsection{Democracy}

It is generally accepted that good governance can flourish only in a democratic environment. On the international level the United Nations as an institution promotes democracy and good governance at every opportunity, but unfortunately the Security Council itself suffers from a serious democratic deficit. The United Nations will have to be restructured if it wishes to function as a legitimate forum of democratic global governance. The lack of democratic structures on the international level is further exacerbated by the customary international law-making process as opposed to the international treaty-making process. Norms of customary international law and ius cogens are created by state practice without any formal democratic participation of role players such as minority groups and the international community of states at large.

\subsection{Sovereignty}

Although the nature of sovereignty has undergone many changes over the past centuries, it can still be described as the cornerstone of the modern interstate system. Good global governance can be established only if states are prepared to accept far-reaching limitations on their sovereignty. The current debate on the legitimacy of humanitarian intervention by one state in the territory of another state is a point in question. At the same time the encroachment upon the sovereignty of states cannot be driven too far as it may lead to the eventual demise of the nationstate as we know it today. It is clear, however, that article 2(4) of the Charter of the United Nations can no longer be interpreted so narrowly that almost anything a state does within its own territory can be classified as falling within the domestic jurisdiction of such a state.

\subsection{Requirements of statehood}

As the binding nature of international law is based to a large extent on the effectiveness of the applicable norms, one of the requirements of statehood has always been an effective government. But in view of the changing nature of international law from the effectiveness of norms to the legality of norms, and the 
heavy emphasis on good governance on both the national and the international level, it is possible to ask if the requirement of an effective government should not be replaced by the requirement of good governance. Such a change would imply amongst other things that states that do not practice good governance should be assisted by the international community (possibly through a reinstatement of the United Nations Trusteeship System) to rectify any deficiencies in order to properly function as fully-fledged members of the international community of states.

\section{Conclusion}

From this very brief overview it should be clear that as global governance and good governance have become key concepts in public international law, no state can afford to simply ignore the political and legal consequences these notions might have on its own position within the international community of states. Yet at the same time it must be stated that the full deployment of these notions in public international law is dependent upon agreement being reached within the international community of states on a number of issues. To re-iterate, states will have to attain clarity and certainty on

- $\quad$ whether or not to extend international legal personality to organisations and institutions other than the current international organisations and states,

- the contents of an international rule of law, together with at least a core of human rights that should bind all states irrespective of cultural differences,

- how to proceed with the democratisation process in undemocratic states and international organisations,

- the extent to which the sovereignty of states could and should be limited, and

- the elevation of the concept of good governance to an independent requirement of statehood.

Surely, this is probably easier said than done. But the reality of ongoing globalisation and the ever-increasing interdependence of states resulting from this process leave the international community of states with no other option but to seriously consider these issues without unreasonably hiding behind their own selfish interests. 